\title{
TP53 NP_000537.3:p.G266V
}

National Cancer Institute

\section{Source}

National Cancer Institute. TP53 NP 000537.3:p.G266V. NCI Thesaurus. Code C146908.

A change in the amino acid residue at position 266 in the cellular tumor antigen p53

protein where glycine has been replaced by valine. 